\title{
Housing sector development in socio-economic space of agglomeration
}

\author{
Yulia Podoprigora ${ }^{1,}$, Irina Volchkova $^{1}$, Maria Danilova $^{1}$, and Evgeniya Ufimtseva $^{1}$ \\ ${ }^{1}$ Tomsk State University of Architecture and Building, 634003 Tomsk, Russia
}

\begin{abstract}
The paper is aimed at studying the influence of balanced housing sector development on the cohesion level of the socio-economic space (SES) in agglomerations. Statistical and comparative analytical techniques are used as the basic methods in this research. The paper presents indicators that measure the level of integration and balance in the housing sector. It proposes a set of mechanisms aimed at promoting a more balanced development of the housing sector in order to achieve SES cohesion in the Tomsk agglomeration. The relevance of the study is associated with intensification of agglomeration processes and the need for new methods and techniques to assess the balanced state of housing sector development in agglomeration SES.
\end{abstract}

\section{Introduction}

Ensuring the balanced socio-economic development of the country, including the housing sector, is one of the priorities in the current national policy of the Russian Federation. Nevertheless, inconsistent housing policies of communities have a number of destructive consequences, including increasing differentiation in the level of socio-economic development across communities and less coherent socio-economic space (SES) of an agglomeration. In this context, the relevance of this study is conditioned by theoretical and practical importance of studying the balanced development processes of the housing sector taking into account the need to increase the cohesion level of agglomeration SES. The conceptual scientific problem of the study is the lack of an updated theoretical and methodological framework necessary for studying and measuring the influence of housing sector development on the cohesion level of agglomeration SES.

Theoretical and applied studies of agglomeration SES were conducted by V. S. Antonyuk, E. Boze, V. L. Glazychev, E. E. Goryachenko, N. V. Demchuk, A. M. Lola, N. L. Mosienko, Z. Z. Mullagaleeva, T. Nelson, I. V. Starodubrovskaya, H. Uchida, A. Franchini, V. A. Shabashev, A. V. Schmidt, etc. [1-7]. Notably, the international experience shows that the level of agglomeration development is often estimated together with the agglomeration effect. A set of criteria used by foreign researchers is usually close to the criteria taken for the Soviet methods developed in the 1970s and 1980s by the Central Scientific Research and Design Institute of Urban Planning and the Institute of Geography of the USSR Academy of Sciences (population density, population size of the core city,

\footnotetext{
${ }^{1}$ Corresponding author: y.v.p@,rambler.ru
} 
temporal availability of the core city) [7]. In the last decade, experts of the Institute for Urban Economics (Moscow) made a valuable contribution to improving methods for assessing the development level of Russian agglomerations. They developed two types of assessment indicators: integration and balanced ones [8].

This study is aimed at assessing the influence of balanced housing sector development on the cohesion level of agglomeration SES. The scientific and practical novelty of the study is associated with the creation of mechanisms aimed at promoting a more balanced development of the housing sector in order to achieve SES cohesion in the Tomsk agglomeration.

\section{Materials and Methods}

The systems theory, the theory of spatial development, concepts proposed by Russian and foreign scientists in the field of agglomeration development serve as a methodological framework of the study. Statistical and comparative analytical techniques are used as the basic methods and approaches in this research. In particular, the statistical analysis is required to assess internal inequality in the agglomeration on the basis of numerical indicators. The comparative analysis is used to compare and analyze dynamic factors of individual indicators that represent the housing sector development in the Tomsk agglomeration.

In our opinion, among the available methodological tools for assessing the balanced state of the housing sector, a technique proposed by the Institute of Urban Economics (Moscow) is the most interesting one. According to the developers of this technique, "when accessing the development level of agglomerations, it is important to focus on indicators that reflect the variability of certain parameters across the agglomeration by using the coefficient of variation" [8].

The Institute's specialists developed the following indicators to assess the balanced state of the housing sector:

- the coefficient of variation in housing availability (in square meters) across the agglomeration;

- the coefficient of variation in housing availability (in housing units) across the agglomeration;

- the coefficient of variation in a proportion of persons who have improved their housing conditions among those who have applied for improving their housing conditions;

- relationship between the ratio of the price per square meter of housing to per capita income in the core city of the agglomeration and the weighted average ratio of price to per capita income in other municipalities of the agglomeration [8].

It is worth noting that the practical use of the indicators listed above is limited and depends on available statistical data.

However, in our opinion, in addition to the coefficients of variation for estimating the inequality within the agglomeration, it is important to use the Theil entropy index, which allows us to decompose the interregional inequality index into two components to reflect intergroup and intragroup inequality [9]. In the case of absolute interregional parity, the Theil index takes a minimum value (zero). As the degree of interregional inequality grows, the Theil index increases. The Theil index can be determined by the following formula:

$$
I T=\sum_{j=1}^{n} \frac{X_{j}}{X} \cdot \ln \left(\frac{X_{j} / P_{j}}{X / P}\right)=\sum_{j=1}^{n} \frac{X_{j}}{X} \cdot \ln \left(\frac{x_{j}}{x}\right),
$$

where $X_{j}$ is the absolute value of the indicator in the $\mathrm{j}$-th territory (municipality); $\mathrm{X}$ is the total value of the indicator for all territories (region or districts); $\mathrm{P}_{\mathrm{j}}$ is the population size of 
the $\mathrm{j}$-th territory; $\mathrm{P}$ is the total population size; $\mathrm{x}_{\mathrm{j}}$ is the value of the indicator in the $\mathrm{j}$-th territory per capita; $x$ is the average value of the indicator for all territories per capita; $n$ is the number of territories; $\ln \left(\mathrm{x}_{\mathrm{j}} / \mathrm{x}\right)$ is the natural logarithm of quotient.

\section{Experiment}

We will estimate the influence of the balanced housing sector development on the SES cohesion level in the Tomsk agglomeration, one of the fastest growing agglomerations in Siberia. In recent years, there is a trend towards increasing new housing construction rates in most communities of the agglomeration (Fig. 1). All municipalities of the Tomsk agglomeration have been steadily expanding their housing stock over the last few years. New housing construction rates are increasing due to various sources of financing, making it possible to reduce the housing deficit significantly and increase housing availability for the agglomeration residents.

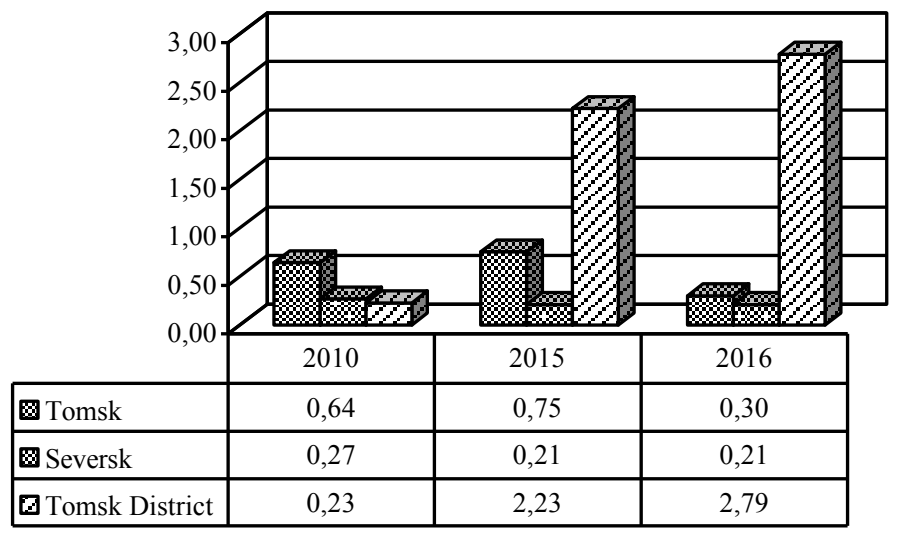

Fig. 1. Commissioning of the total housing area, $\mathrm{m}^{2}$ per capita.

Agglomeration interactions in the housing sector are becoming more intense as evidenced by growing individual housing construction rates in the Tomsk District. The real estate and land market of this district is particularly attractive for the agglomeration residents. However, the development of interactions in the housing sector of the Tomsk agglomeration is highly constrained by limited availability of the housing stock in Seversk closed administrative and territorial entity [10].

Next, the balance of the housing sector development in the Tomsk agglomeration is assessed. For this purpose, we calculate the coefficient of variation and the Theil index for the indicator of residential buildings commissioned in the agglomeration per capita (Table 1). The choice of this indicator is associated with its analytical properties and the availability of statistical data.

Table 1. Analysis of dynamics of residential buildings commissioned in the Tomsk agglomeration per capita.

\begin{tabular}{|l|c|c|c|c|c|c|}
\hline Index & 2011 & 2012 & 2013 & 2014 & 2015 & 2016 \\
\hline $\begin{array}{l}\text { Coefficient of } \\
\text { variation, \% }\end{array}$ & 23.8282 & 22.9928 & $\mathbf{4 5 . 5 9 7 6}$ & $\mathbf{4 5 . 9 3 4 5}$ & 16.6626 & 22.8965 \\
\hline Theil index & 0.0691 & 0.0379 & 0.0163 & 0.1022 & 0.6064 & 0.5876 \\
\hline
\end{tabular}


The calculated coefficient of variation shows that the indicator of residential buildings commissioned in the Tomsk agglomeration in 2013-2014 per capita is distributed unevenly (since the coefficient of variation exceeds 33\%). The calculated Theil index indicates a significant increase in the differentiation within the agglomeration in 2015 as compared to 2014, which negatively affects the coherence of the social and economic space in the Tomsk agglomeration.

\section{Results}

The results of the analysis demonstrate an increased differentiation within the Tomsk agglomeration in terms of the residential houses commissioned per capita in 2015. This has negative effect on the cohesion of the agglomeration SES and requires development of mechanisms aimed at promoting a more balanced development of the housing sector (Fig. 2).

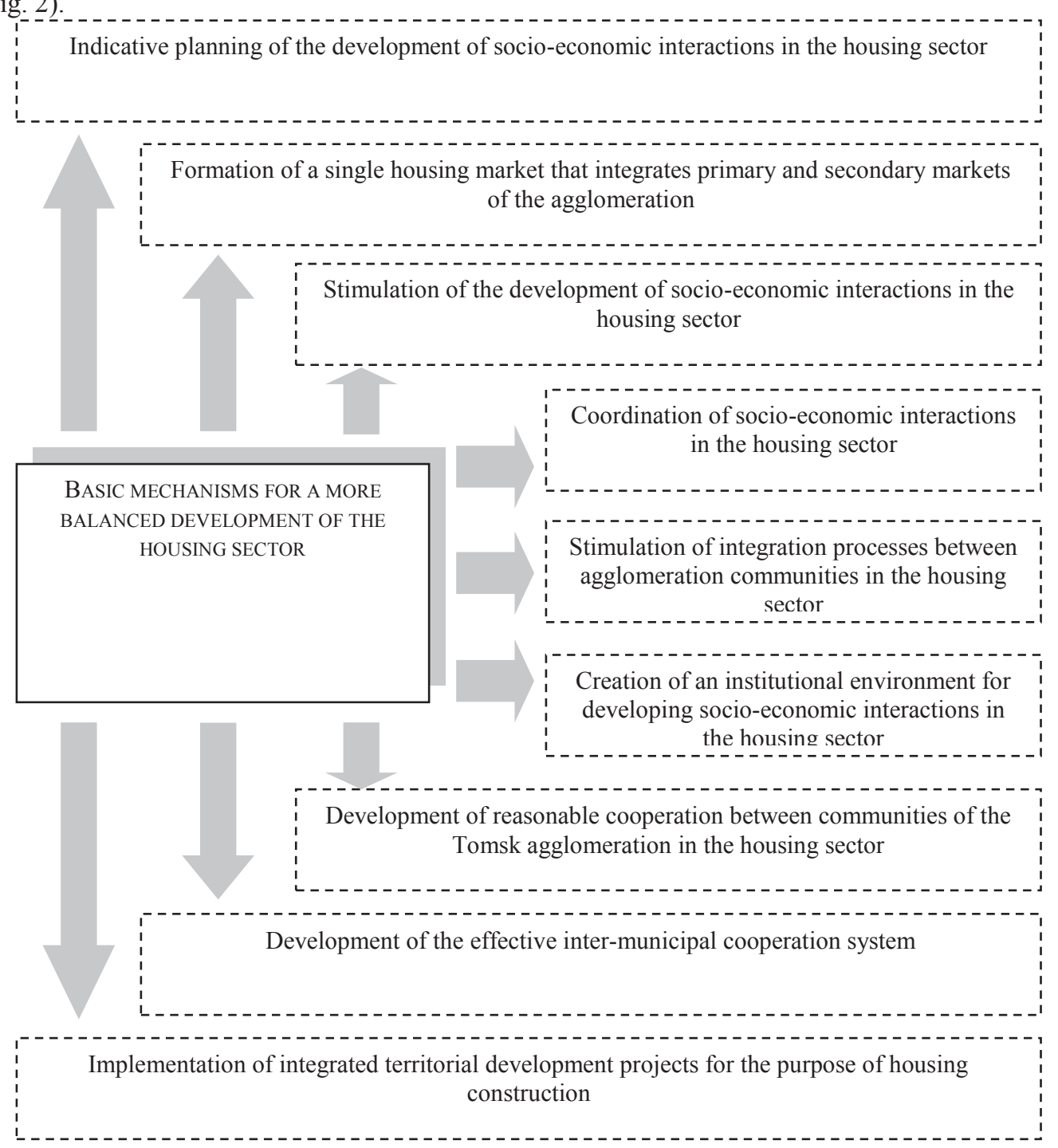

Fig. 2. Mechanisms for a more balanced development of the housing sector. 


\section{Conclusion}

The analysis shows that assessing the balance in the housing sector development in the agglomeration SES is an important task. We assume that by converging levels of socioeconomic development across communities and enhancing SES cohesion, it is possible to make the economic sector of the agglomeration more sustainable, reduce social inequality, increase the competitiveness of the agglomeration, as well as to create single agglomeration markets, strengthen integration, and eventually improve the welfare of residents.

In our opinion, the mechanisms aimed at balancing the housing sector in the Tomsk agglomeration should be based not only on methods regulating socio-economic interactions, but also on methods that focus on creating an environment for such interactions. It is also important to emphasize that the balance can be achieved both through self-regulation and direct regulation by local authorities of municipalities belonging to the agglomeration. Taken together, the efforts to achieve more balanced agglomeration processes in the housing sector enhance the quality of these processes and increase the general level of agglomeration development.

The presented mechanisms, in turn, imply using a certain set of tools for their implementation. For example, stable relations between SES agents based on equal opportunities of the agents in their socio-economic interactions will contribute to the balanced development of the housing sector in the Tomsk agglomeration. Equal opportunities should be provided through such basic tools as coordination of goals, opportunities, interests, responsibilities, as well as the coordination of partner relations among SES agents.

The results of the study can serve as a basis for improving the methodological framework that is necessary for studying and measuring the influence of the single housing market development on the cohesion level of the socio-economic space in agglomerations.

\section{References}

1. V. Glazychev, I. Starodubrovskaya, et al, Chelyabinskaya aglomeratsiya: potentsial razvitiya [Chelyabinsk agglomeration: the development potential] (The Institute of Economics and Law, Chelyabinsk, 2008) (in Russian)

2. E.E. Goryatchenko, N.L. Mosienko, N.V. Demchuk, Region: Economics and sociology, 3, 94-112 (2011)

3. A.M. Lola, Urban and Agglomeration Control in Russia: state and what to do (Moscow, 2013)

4. E. Bose, Russian expert review, 4-5(22), 13-16 (2007)

5. Z.Z. Mullagaleeva, V.A. Shabashev, Teoretiko-metodologicheskie osnovy jekonomicheskoj politiki gorodov, obrazujushhih aglomeraciju [Theoretical and methodological foundations of economic policy of the cities, forming the Metropolitan area] (Kuzbassvuzizdat, Kemerovo, 2009) (in Russian)

6. A.V. Schmidt, V.S. Antonyuk, A. Franchini, Economy of Region, 12(3), 776-789 (2016)

7. H. Uchida, T. Nelson, Working Paper, World Institute for Development Economics Research, 29, (2010)

8. Institute for Urban Economics, Koncepcija ocenki urovnja razvitija gorodskih aglomeracij [Evaluation concept of urban agglomerations development], available at: http://www.urbaneconomics.ru/sites/default/files/koncepciya_ocenki_urovnya_razviti ya_gorodskih_aglomeraciy_13.01.17.pdf(2017) (in Russian)

9. N.V. Voroshilov, Problems of Territory's Development, 3(65), 31-41 (2013) (in Russian) 
10. I.V. Volchkova, M.N. Danilova,Y.V. Podoprigora, A.A. Seliverstov, E.V. Ufimtseva, N.R. Shadeyko, Razvitie aglomeracionnyh processov $v$ aspekte svjazannosti social'nojekonomicheskogo prostranstva (po materialam Tomskoj aglomeracii) [The development of the agglomeration process in the aspect of connectedness socioeconomic space (on materials of the Tomsk agglomeration)] (Integral cover, Tomsk, 2016) (in Russian) 